\title{
Constructivism Approach to Increase the Knowledge and Appreciation in History among Secondary Student
}

\author{
Muhammad Zulfiqar Mat Lui ${ }^{1}$, Mahzan Awang ${ }^{2,}$ Abdul Razzaq Ahmad ${ }^{3} \&$ Asmahani \\ Muhthar ${ }^{4}$ \\ ${ }^{1234}$ Faculty of Education UKM, MALAYSIA
}

E-mail: zulfiqarmuhammad1992@gmail.com

\begin{abstract}
History education is always been a problem to the student. Most of them think that history is boring subject. Overall, history is not a favorite subject among the students because there are too many facts to remember and some of them could not even understand the terms used in the history subject. Other than that, the students also fail to answer the general knowledge and critical thinking questions. The scholar makes a lot of research regarding the issue and problems and able to construct theories for history education. This paper is discussing about constructivism approach to increase the knowledge and appreciation in history among secondary students. By using the constructivist approach, it will able to help the students to learn history much better and the teacher could transform their way of teaching to make the lesson more interesting and fun.
\end{abstract}

Keywords: Constructivism, History Education, Knowledge, Critical Thinking

\section{Introduction}

History education is an important area of knowledge in the education system worldwide. Most countries are focusing in history subject because history teaches people about the origin and process of nation-building. History has a lot to do with the perspective of people's lives in Malaysia. History education is capable of shaping people's identity for the better. For example, the spirit of patriotism in society will increase to the point of being willing to sacrifice our possessions and lives. Also, moral values such as good manners, the spirit of love for the homeland, tolerance and so forth can be formed.

It has been proven that history educates the public with stories of historical significance such as the story of heroism in Islam, the story of the Sabil War, the myths of Malay heroism and the history of nation-building. This shows that history has told a chronology of causes and consequences. Furthermore, history seems to serve as a reminder to society. If no teaching is taken, then the history that has taken place will be repeated. History not only educates in terms of chronology, morals, and teaching but is fundamental to the founding of nation-states. The best 
example of this is the formation of Malaysia after being colonized by foreign countries from 1511 until 1957. The period of colonization lasted for 446 years. For nearly half a century it has taught the people especially the Malay to break free from the clutches of foreign power that oppresses and creates an independent nation in body and mind.

The teaching and education of history has opened the minds of the people and has been a source of inspiration for improving the present and the future and trying to reiterate the greatness that had been achieved before the occupation of which this Malay land had become a respected great power in foreign countries until it was called the Golden Peninsula. Besides, the country is rich in produce, great leaders and rich in manners and manners. Therefore, historical education is still relevant and should be borne with pride in the heart.

This article emphasizes on the approaches used to educate students and especially high school students in enhancing their knowledge and appreciation of history. This issue is where history is a subject that students are not interested in because it is related to remembering many facts. Besides, the way teachers teach is also a factor in students' difficulty in remembering historical facts. The views of the society are also an element of historical knowledge. The people of the surrounding community feel that this historical knowledge is not important and does not apply in the realm of work. Thus, students have embedded the notion that history subject is tend to be difficult, tedious to learn and completely useless especially in the working environment. Therefore, this concept paper is written to change students' perceptions of history in school and the approach that will be used that is constructivism approach.

Constructivism approaches is one approach that historians need to adopt. According to a study from Azizi Yahaya \& Jaafar Sidek Latif (2005), this approach can create competitive students and enhance their skills and thinking in science and thus educate students to think outside of the box. It also transforms the way of learning in terms of memorization into a total comprehension session in any given learning. Besides, according to Nair \& Malar Muthiah (2005) Sub district in their study, constructivism approaches that use schema models can enhance teaching comprehension and significantly improve subject comprehension. Therefore, guidance from the teachers is very important in helping students to understand history.

\section{Concepts of Constructivism}

Constructivism is an approach that describes the formation of knowledge in the human mind. Based on the experience and knowledge gained through the learning process, students and teachers have developed new insights and ideas to facilitate the learning process. The ideas that come into being are shaped by students and teachers only as a mentor. According to Briner, M (1999) ideas and approaches are tested by students based on existing experiences and they apply and integrate this knowledge and experiences into new situations using existing materials.

According to Sushkin, N (1999) students are more stressed in this theory than teachers. Interaction with experience, knowledge, and materials can build an understanding of a situation. Therefore, the concept and solution of the problem was developed by the student himself. In other words, this theory is more student-centered than teacher-centered. This approach is great for improving the learning process as students can develop a genuine concept based on the knowledge they have learned. This process can enhance their understanding of something. Student achievement in science is higher with the application of this constructivism approach than traditional teacher-based methods. In Noriati's study, Boon Pong Ying \& Sharifah Fakhriah Syed Ahmad (2009) stated that constructivism means the construction of knowledge. New ideas are generated through cognitive growth and learning.

Among those who pioneered this concept of constructivism was Lev Semyonich Vygotsky (1978). A Soviet psychologist who wrote the book Mind in Society. He has created a borderline of free-thinking and language and has grown apart and concentrated in the proximal developmental zone more relevant to teaching technology. Apart from Vygotsky, another character is Jean Piaget (1976). According to his textbook To Understand is to Invent: The Future of Education has described the language of knowledge evolving as a result of knowledge building after an individual's understanding. According to him, knowledge is inherent and will change over time. Therefore, this approach goes beyond the description of the formation of knowledge in the mind of a human being and forms a new concept in teaching and learning.

There have been numerous studies on the approach of constructivism. There is a model based on the process of constructivism, which is Needham's Five-Phase Constructivism Model, which was founded by Needham (1997). Needham used a model he developed to see the process of improving understanding and learning in a concept and encouraging students to become actively involved in the classroom. The use of this theory of constructivism is very rarely used in historical subjects. According to Subadrah Nair and Malar Muthiah (2005) in their study, they explained the use of Needham's Five Phase Constructivism Model. The study was also used to determine 
whether the use of this method is effective in improving learning outcomes for students. In this model, there are five phases used: among them:

a) Orientation Phase: This phase begins with teachers trying to stimulate student interest in a learning subject by using teaching aids such as ICT. Some of the most commonly used ICT applications are video, movie, powerpoint, Prezi, and documentary. It also uses novels, comics, newspaper clippings, plays, simulations and more.

b) Through this phase, students are given the option to explore information and control their learning process (Samin \& Mustapha, 2005).

c) Ideal Phase: This phase is the beginning of the discussion and re-processing of teaching aids. Students will be guided by teachers for discussion sessions, writing reports and developing new knowledge using existing knowledge. This discussion session was conducted with a group member.

d) Idea Structuring Phase: Through this phase, teachers will provide students with a structured assignment so that they can review all of the original ideas that they have developed or review all of their peer ideas and they will build an original skill structure. and more effective. Also, students can change or rearrange ideas to be more organized and organized. Here teachers act as mentors by reinforcing the ideas of their students.

e) Idea phases: New ideas created by students will be applied to solve problems in new situations. This situation will create a new understanding and encourage the process of inquiry within the students.

f) Reflection Phase: This phase is the final phase in this model, In this phase, the process of comparing existing knowledge with the new knowledge created by them. Students can reflect on their ideas and teachers will monitor the students' writing, group discussions and personal notes to see how well they understand.

This model has been widely used in various studies. According to Lee \& Zainal (2018), this approach is widely used in many subjects such as engineering, art and science subjects. The ideas that students put into this approach can enhance students' understanding and deepen their knowledge of the subject. This approach is more practical than the traditional method used by most teachers and students where the teacher simply explains the content and students will memorize without understanding the essence of the subject.
There are many benefits to learning by using this approach. First and foremost is that students can think more clearly by generating new knowledge and being able to solve problems and make wise decisions in a variety of situations. Research and investigation processes such as identifying problems, collecting and processing data and building conclusions can be done more carefully. Second is that students can understand concepts and concepts more clearly and apply them in life. Third is the concept of learning that can be remembered longer because students can build new knowledge through the acquisition of existing knowledge. Fourth is that students' confidence increases because they already know and understand the concept of learning and are brave in real-life situations and finally, social skills can be developed where they can work with others without problems. The resulting interaction can help them improve their knowledge.

In 2014, the Ministry of Education Malaysia introduced a concept that is 21 st Century Learning or PAK21. This concept is a process whereby learning at school is student-centered rather than teacher-centered. Among the basic standards in PAK21 are the elements of communication, collaboration, critical thinking, creativity and the application of pure and ethical values. Based on the elements introduced by the Ministry of Education Malaysia, the teaching and learning process will be more interesting and effective because each of these elements has a real and positive impact on students.

A good example is a communication element. There is a two-way communication in learning where teachers communicate with students. This means that there is feedback on the learning process taught by the teacher. Teachers provide many constructive comments as well as teamwork can also be achieved through such communication. Also, critical thinking can be instilled in which students will evaluate in a given subject as well as other elements such as creativity, the application of pure values and ethics. It has been proven that the concept of PAK21 is in line with the constructivism approach whereby existing knowledge processes are redefined into new knowledge and this has changed students' perception of the learning and teaching process in the classroom. Besides, the attitude of the students to the pursuit of knowledge is improved and shows a high degree of motivation. As an example of a study conducted by Rahim and Sharifuddin (2014), this concept of PAK21 shows positive effects among native learners on Malay language learning. This means that the impact of this concept provides a positive relationship with students' attitude and motivation

This concept is introduced in line with this approach to constructivism. This PAK21 is suitable for all subjects as 
it is in keeping with the current developments and use of technology today.

\section{Issues and Challenges in History Education in Malaysia}

The subject of history has been an important subject in the education system in Malaysia for a long time. Begin with elective subjects only where students are free to choose geographical or historical subjects. However, in 2010, the subject of history became a core subject and required graduation beginning in 2013. There are issues and challenges in this subject involving both teachers and students. Many factors contribute to issues and challenges in history education. Among the frequently raised issues are student achievement in history education, student perceptions of history subjects and aspects of teaching history teachers. These issues are just a few of the issues that exist in Malaysian education history.

Title and syllabus the history of secondary schools, especially Forms 4 and 5, has been the same since 2000. The history of grades 1 through 3 alone has changed topics and concepts. Where the topic of world history has been taught to students of level 1 begins with the definition of history, prehistory. In pre-historic topics, it has been deeply embedded in the ice age. Form 1 history studies have also introduced historical terms such as the Pliocene, Holocene and Pleistocene periods and also an early exposure to the topics of early civilization, Greek and Roman civilizations, Chinese and Indian civilizations and the topic of Islamic civilization. This is a challenge for students starting in 2017 to understand the new syllabus introduced by the Malaysian Ministry of Education

There are many weaknesses related to learning and teaching issues in the subject of history. This issue is visible to parties, teachers and students. The issue that students bring up is that history is a boring subject. This problem not only occurs in Malaysia but overseas such as Australia and Canada. According to Clark (2008), students in the country also state that the subject of history is boring. Therefore, various ways and studies have been conducted by Australian and Canadian leaders to enhance the learning of history in schools. This issue is very serious as it involves the younger generations who will become leaders in the country. If this generation is not educated with the knowledge of history, then the patriotic nature within them will diminish and can lead to the collapse of civilization and morality. The original culture of the country will also be endangered and perishable.

This problem can also be seen in Malaysia as a comparative study shows that problems related to historical education in Australia and Canada have a similarity with Malaysia's lack of student interest in historical subjects. Among the issues raised by students is the repetition of topics in the history curriculum. For example, the history topics taught at level one will be repeated at Form four. There is, however, a slight addiction to the four-level topic but it does not deny that there are similarities between the one and four-level topics. Therefore, the preparation of the history curriculum needs to be updated to encourage students to become bored in the classroom.

The next issue is about teachers who do not play a role in the classroom. The process of facilitating does not happen and the teaching method is teacher-centred rather than student-centred. The teacher just explained the topic and there was no discussion between the teacher and the student. Also, the lack of study aids is a factor in history education. Less creative and more instructive way of answering the exam questions causes students to become bored and misunderstood the concept of historical learning.

The next issue involves the history textbook. This subject is not subject to sensitive facts such as religion and racism. Facts like this are left to be controversial to maintain racial harmony. This issue is due to the lack of student awareness because it is not exposed to the truth recorded in history books. Besides, students are not exposed to historical sources such as documents, artefacts and manuscripts. This approach is not used in the classroom but also stimulates students' interest in the history of history.

The challenge that teachers need to take is to change the way they teach in the classroom. Traditional methods based on teachers must be changed to a better one. Communication skills between teachers and students need to be improved so that better and more effective two-way communication is possible. Not just textbooks but the use of comics, novels, graphic novels, movies, dramas and animations to make learning more interesting.

\section{Conclusion}

Constructivism approaches are a great way to enhance students' skills in history. Students and teachers need to understand that history is not a science to memorize facts but rather to study the origin and period because history has the advantage of forming a successful nation and nation. Success in educating people in history depends on the right way of presenting and understanding the true concept of history. If the education is given properly, then the people who are born will have a high awareness of history and form a highly educated and critical-minded civilization.

\section{References}


[1] Adam, A. (2014). Pendidikan Sejarah di Malaysia Dewasa ini: Sejauh Manakah ia Relevan kepada Pembinaan Nasion?. SUSURGALUR, 2(1).

[2] Iberahim, A. R., Mahamod, Z., \& MOHAMMAD, W. M. R. W. (2017). Pembelajaran Abad Ke-21 Dan Pengaruhnya Terhadap Sikap, Motivasi Dan Pencapaian Bahasa Melayu Pelajar Sekolah Menengah (21th Century Learning and the Influence of Attitude, Motivation and Achievements Malay Language Secondary School Student). Jurnal Pendidikan Bahasa Melayu, 7(2), 77-88.

[3] Jasin, Z. M., \& Shaari, A. S. (2016). Keberkesanan Model Konstrukktivisme Lima Fasa Needham dalam Pengajaran KOMSAS Bahasa Melayu. Jurnal Pendidikan Bahasa Melayu, 2(1), 79-92.

[4] Lan, Y. S. (2013). Gabungan Pendekatan Konstruktivisme Dan Behaviorlisme Bagi Meningkatkan Prestasi Mata Pelajaran Sejarah Tingkatan Tiga. In Seminar Pendidikan Sejarah Dan Geografi. UMS.(29-30 Ogos)

[5] Lee, M. F., Yusoff, S. N. M., Tan, K. H., \& Lim, J. S. C. (2019). Needham Model Based Instructional Multimedia Material for Teaching Digital Logic Gates. Journal of Technical Education and Training, 11(1).

[6] Nair, S. 2005. Penggunaan model konstruktivisme lima fasa needham dalam pembelajaran sejarah. Malaysian Journal of Educators and Education, 20. 21-41

[7] Talin, R. (2014). The teaching of history in secondary schools. International Journal of Social Science and Humanities Research, 2(3), 72-78.

[8] https://www.pendidik2u.my/pembelajaran-abad-ke-21pak21/ diakses pada 3 September 2019 